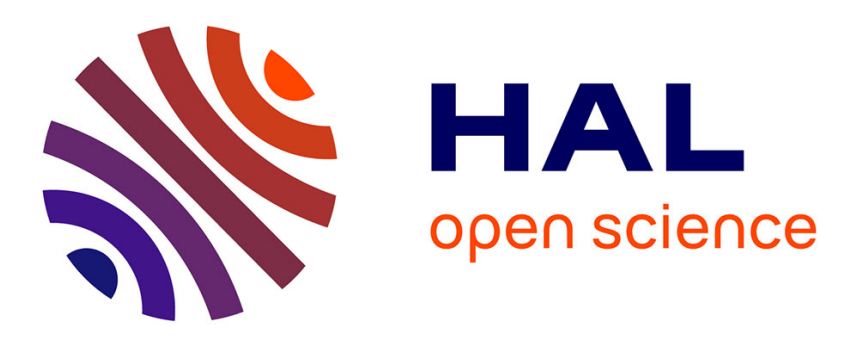

\title{
Nitrogen deficiency and recovery in sustainable corn production as revealed by leaf chlorophyll measurements
}

Jun Zhang, Alfred M. Blackmer, Tracy M. Blackmer, Peter M. Kyveryga, Jason W. Ellsworth

\section{- To cite this version:}

Jun Zhang, Alfred M. Blackmer, Tracy M. Blackmer, Peter M. Kyveryga, Jason W. Ellsworth. Nitrogen deficiency and recovery in sustainable corn production as revealed by leaf chlorophyll measurements. Agronomy for Sustainable Development, 2007, 27 (4), pp.313-319. hal-00886372

\section{HAL Id: hal-00886372 \\ https://hal.science/hal-00886372}

Submitted on 1 Jan 2007

HAL is a multi-disciplinary open access archive for the deposit and dissemination of scientific research documents, whether they are published or not. The documents may come from teaching and research institutions in France or abroad, or from public or private research centers.
L'archive ouverte pluridisciplinaire HAL, est destinée au dépôt et à la diffusion de documents scientifiques de niveau recherche, publiés ou non, émanant des établissements d'enseignement et de recherche français ou étrangers, des laboratoires publics ou privés. 


\title{
Nitrogen deficiency and recovery in sustainable corn production as revealed by leaf chlorophyll measurements
}

\author{
Jun ZHANG ${ }^{\text {** }}$, Alfred M. BLACKMER ${ }^{\mathrm{a}}$, Tracy M. BlACKMER ${ }^{\mathrm{b}}$, Peter M. KYVERYGA ${ }^{\mathrm{a}, \mathrm{b}}$, \\ Jason W. ELLSWORTH \\ ${ }^{\text {a }}$ Department of Agronomy, Iowa State University, Ames, IA 50011, USA \\ ${ }^{\mathrm{b}}$ Iowa Soybean Association, 4554 114th Street, Urbandale, IA 50322, USA \\ ${ }^{c}$ Wilburn Ellis Ag Division, 150 Burlington Avenue, Pasco, WA 95301, USA
}

(Accepted 30 March 2007)

\begin{abstract}
Assessing economic and environmental impacts of nitrogen $(\mathrm{N})$ fertilization in production agriculture is important for preventing unnecessary application of $\mathrm{N}$ fertilizer and avoiding losses of this $\mathrm{N}$ into water body. Chlorophyll meters are often used to evaluate $\mathrm{N}$ management practices and diagnose deficiencies of $\mathrm{N}$ in corn (Zea mays L.). Chlorophyll meter readings (CMRs) are usually interpreted relative to reference readings taken from plants having ample $\mathrm{N}$ to maximize rates of growth. Although measurements taken with chlorophyll meters provide a scale for estimating the sufficiency of $\mathrm{N}$ for corn growth, effects of above-optimal supplies of $\mathrm{N}$ on the measurements have not been studied when diagnosing $\mathrm{N}$ deficiencies during vegetative growth stages. Here, temporal trends in chlorophyll measurements were monitored in trials where various rates of $\mathrm{N}$ were applied soon after planting and (or) after symptoms of $\mathrm{N}$ deficiency had developed due to the changes of $\mathrm{N}$ status in soil and demand for $\mathrm{N}$ during corn growth. Divergence of chlorophyll measurements from the reference readings occurred in situations where plants having too little $\mathrm{N}$ were compared with plants having adequate $\mathrm{N}$. In contrast, convergence of chlorophyll measurements with the reference readings after application of fertilizer $\mathrm{N}$ during the growing season indicated partial or complete recovery of the plants from the deficiency of $\mathrm{N}$. The recovery can be explained by considering that luxury production of chlorophyll occurred at higher rates of fertilization or by interactions of $\mathrm{N}$ with soil water and other nutrients supplied during corn growth. Observations that plants can partially or completely recover from periods with inadequate $\mathrm{N}$ for chlorophyll production suggest that the leaf chlorophyll measurements taken early in the season should not be always expected to highly correlate with final yields of grain. Therefore, it is important to recognize the possible recovery of chlorophyll production and to avoid $\mathrm{N}$ losses to the environment.
\end{abstract}

corn (Zea mays L.) / nitrogen deficiency / chlorophyll meter / luxury production / temporal trend

\section{INTRODUCTION}

The success of an environment protection program depends on a quick recognition and effective control of pollution sources. Application of $\mathrm{N}$ fertilizers carries important environmental issues in sustainable corn production because nitrate $\left(\mathrm{NO}_{3}^{-}\right)$, one of the major agriculture-derived pollutants leaching to groundwater on a watershed scale (Liu et al., 2005), is part or a transformed form of the $\mathrm{N}$ fertilizer products commonly used in the Corn Belt of the USA. Studies focusing on use of site-specific management to improve the efficiency of $\mathrm{N}$ fertilization are increasingly needed in production agriculture. Chlorophyll meters have been widely used as tools for diagnosing deficiencies of $\mathrm{N}$ during the growth of corn (Piekielek and Fox, 1992; Schepers et al., 1992; Wood et al., 1993; Zhang and Blackmer, 1999; Scharf et al., 2006). Severe deficiencies of $\mathrm{N}$ can be diagnosed early in the season because shortages of $\mathrm{N}$ limit the rates of dry matter production. To minimize the

\footnotetext{
* Corresponding author: jun.zhang@wright.edu.
}

Present address: Statistical Consulting Center, Wright State University, 3640 Colonel Glenn Highway, Dayton, OH 45435, USA. effects of other factors that can limit production of chlorophyll and dry matter, chlorophyll meter readings (CMRs) are usually transformed to "relative CMRs" that are expressed as a percentage of the CMR observed on plants growing under similar conditions, except enough fertilizer $\mathrm{N}$ has been added to ensure non-limiting supplies of $\mathrm{N}$ for growth (Denuit et al., 2002). Deficiencies of $N$ are considered to occur when relative CMRs are less than 90\% (Hussain et al., 2000), 92\% (Jemison and Lytle, 1996), 93\% (Piekielek et al., 1995), 95\% (Piekielek and Fox, 1992; Varvel et al., 1997), or 98\% (Shapiro, 1999) of those observed for plants in reference plots or strips. The wide range of the critical values might be due to hybrid differences and variation in non-limiting supplies of $\mathrm{N}$ or other field conditions. Schepers et al. (1992) noticed a saturation of the chlorophyll meter for highest chlorophyll contents. Other researchers stated that relative CMRs are not greatly affected by more $\mathrm{N}$ than needed for corn growth (Peterson et al., 1993). Many diagnoses are based on the assumption that leaf chlorophyll content and CMRs are essentially the same whether supplies of $\mathrm{N}$ exactly match or greatly exceed the amounts of $\mathrm{N}$ needed to maximize growth. This assumption may seem reasonable due 
to the fact that plants show diminishing effects to incremental increases in rates of $\mathrm{N}$ fertilization as yields asymptotically approach a maximum. However, it is practically impossible to define exactly when a maximum yield is reached (Binford et al., 1990, 1992). Moreover, yield differences smaller than about $7 \%$ usually cannot be detected in most studies (Fox et al., 2001). An over-fertilized plot as reference is not suitable for determining the supplemental $\mathrm{N}$ required (Denuit et al., 2002). We can find no evidence of comprehensive efforts to identify effects of the extra $\mathrm{N}$ that may introduce uncertainty or errors into diagnoses at near-optimal supplies of $\mathrm{N}$.

The use of chlorophyll meters to diagnose $\mathrm{N}$ deficiencies is based on observations that relative CMRs show predictable relationships with relative yields, i.e., yields expressed as a percentage of the highest yields that can be attained by adding fertilizer under other conditions. The underlying phenomenon involved was first called poverty adjustment by Macy (1936) and is widely accepted with tissue analysis that is used to diagnose nutrient deficiencies in plants. Poverty adjustment occurs in situations where a change in the supply of $\mathrm{N}$ results in a change of $\mathrm{N}$ concentration in tissues and a change of yield. Therefore, changes in $\mathrm{N}$ concentrations of tissues can be used to assess the sufficiency of $\mathrm{N}$ for plant growth. Relative yield levels near $95 \%$ are often considered optimal (Piekielek et al., 1995), which are less than the maximum yields attainable by adding fertilizer because the costs of this fertilization exceed the benefits.

Possible effects of more $\mathrm{N}$ than needed to maximize yields should be expected because it is well established that plants can take up extra $\mathrm{N}$ for biomass growth. Macy (1936) coined the term luxury uptake of nutrients, which refers to a fertilizerinduced increase in uptake of $\mathrm{N}$ that was not accompanied by an increase in yields. This concept is widely recognized in plant tissue analysis to characterize sufficiency of nutrients for plant growth.

Failure to recognize the over-dosage of $\mathrm{N}$ application in intensive farming leaves a serious barrier in promoting sustainable farming and in protecting the environment. We report evidence for a process called luxury production of chlorophyll that is similar to luxury uptake of nutrients in corn and discuss the significance of this process when monitoring for deficiencies of $\mathrm{N}$ during the growth of corn. The evidence relates to convergence of chlorophyll measurements of corn leaves (partial or complete recovery from the deficiency of $\mathrm{N}$ ) during reproductive growth, i.e., the second half of the growing season.

A deficiency of $\mathrm{N}$ can be defined as a shortage of $\mathrm{N}$ that restricts the growth of plants, even if it is only for a short period of time (Greenwood, 1976). When chlorophyll meters are used, a deficiency of $\mathrm{N}$ is indicated by a restricted production of chlorophyll that can be considered an indicator for $\mathrm{N}$ status of the crop. Relatively low CMRs and low yields are both symptoms of an $\mathrm{N}$ deficiency that has occurred earlier. Therefore, these symptoms should not be confused with the deficiency itself.

It is possible to indirectly measure the magnitude of a deficiency by using the concept of $\mathrm{N}$-sufficiency levels, i.e., supply relative to demand. The sufficiency of $\mathrm{N}$ for plant growth can be assessed by measuring plant responses to added $\mathrm{N}$.
Measurements of plant response usually involve comparisons of dry matter accumulation by plants during periods where all factors are the same except for $\mathrm{N}$ supplies from both soil and fertilizer. Estimates of $\mathrm{N}$ deficiencies derived from relative CMRs during the season are of special interest. In this case, fertilizer needs are estimated under conditions where the magnitude of uncertainty is substantially less than when they are estimated before crops are planted. Any estimate of optimal rate of $\mathrm{N}$ made before harvest, however, still includes uncertainty not included in the estimates based on final yields (Kyveryga, 2005). The practical value of using chlorophyll meters to diagnose deficiencies of $\mathrm{N}$ should be measured in terms of their ability to specify the optimal rates of $\mathrm{N}$ fertilization when observations are made over a sufficient range of conditions.

Most $\mathrm{N}$ fertilizer recommendations developed in the past for the Corn Belt of the USA focused only on rates of application, rather than on methods and times of application. Such recommendations essentially ignored evidence that the efficiency of $\mathrm{N}$ fertilizer greatly depends on how the fertilizer is applied and that substantial losses of $\mathrm{N}$ can occur if it is not carefully managed. In situations where supplies of $\mathrm{N}$ are either substantially less or greater than the optimal level for production of grain, the symptoms of past deficiencies should be expected to be good predictors of whether or not deficiencies of $\mathrm{N}$ will occur in the future. The in-season chlorophyll measurement can help to adjust the $\mathrm{N}$ fertilizer rate in order to meet actual $\mathrm{N}$ demand of crops and prevent losses of $\mathrm{N}$ to the environment. The studies reported here, therefore, are focused on problems encountered when near-optimal rates of $\mathrm{N}$ are applied and chlorophyll meters are used to evaluate and (or) refine estimates of fertilizer need. Monitoring the $\mathrm{N}$ status of the crop permits corrective management to reduce yield losses from $\mathrm{N}$ deficiency.

\section{MATERIALS AND METHODS}

Experiments were conducted in 1998 and 1999 at four sites in Boone, Hamilton, and Greene counties of Iowa, USA. Each field was larger than 25 hectares in size and planted to corn in late April or early May following soybean (Glycine max L. Merr.). Tillage, hybrids and dates for planting and fertilization are listed in Table I. The tillage practices and corn varieties were selected to represent their popularity in the Corn Belt of the USA. All fields were managed by farmers using their normal practices except for $\mathrm{N}$ fertilizer treatments.

Fertilizer treatments consisted of various combinations of rates and application time of liquid urea-ammonia-nitrate (UAN, 28\% N) and were applied to 6-row strips going the lengths of the fields. No fertilizer $\mathrm{N}$ was applied in the previous fall or before planting corn. The time-of-application treatments were soon after planting (referred as "early N", corresponding to the growth stages V2 to V3 as described by Ritchie et al., 1993) and sidedress (referred as "in-season N", corresponding to the growth stages V10 through V13). The early application included $0,56,112,168$ and (or) $224 \mathrm{~kg} \mathrm{Nha}^{-1}$ that was injected midway between every other 
Table I. Tillage practice, hybrids and dates for planting and fertilization at four sites included in this study.

\begin{tabular}{lcccc}
\hline Factor & Site 1 & Site 2 & Site 3 & Site 4 \\
\hline Tillage & No-till & Conservation & No-till & Conservation \\
Hybrid & Pioneer 34R06 & Dekalb 595 & Merschman 7114 & Great Lakes 5050 \\
& (Medium Bt) & (Top-cross high oil) & (114-day maturity) & $($ 104-day maturity) \\
Planting date & 26 April 1998 & 2 May 1999 & 27 April 1998 & 11 May 1999 \\
Early N & 19 May & 27 May & 13 May & June \\
In-season N & 1 July & 10 July & 8 July & July \\
\hline
\end{tabular}

row to a depth of $15 \mathrm{~cm}$ in strips. The in-season application involved uniformly dribbling the liquid UAN on the soil surface between every other row at rates of 56 and $112 \mathrm{~kg} \mathrm{~N} \mathrm{ha}^{-1}$ at Sites 1 and 3 and $56 \mathrm{~kg} \mathrm{~N} \mathrm{ha}^{-1}$ at Sites 2 and 4. The highest rate $\left(224 \mathrm{~kg} \mathrm{Nha}^{-1}\right)$ at Sites 1 and 3 was split into halves for early and in-season applications. All treatments were replicated 3 to 5 times in a stratified block design.

Five blocks were selected from each field to minimize within-area variation in soil characteristics and represent spatial variation among blocks. Each block extended $12 \mathrm{~m}$ along the rows and was wide enough to include all $\mathrm{N}$ treatments within a block. The block was divided into plots that corresponded to the strips having different $\mathrm{N}$ treatments. Within each plot, CMRs were measured using Minolta SPAD-502 meters on 30 plants randomly selected from the center four rows in June through September (corresponding to the growth stages V4 through R4, as described by Ritchie et al., 1993) at approximately one-week intervals. The device measures the light transmittance of the corn leaf at red wavelength $650 \mathrm{~nm}$ and near-infrared wavelength $940 \mathrm{~nm}$. The ratio of the measurements at two different wavelengths is dimensionless and proportional to chlorophyll content in the leaf. The youngest fully expanded leaf was used for measurement until the tassels emerged; thereafter the ear-leaf was measured (Zhang et al., 2007). All readings were taken halfway between the stalk and leaf tip. Relative CMRs for each treatment were obtained by expressing the CMR in a lower $\mathrm{N}$ rate plot as a percentage of the CMR in the highest $\mathrm{N}$ rate plot within the same block. Least significant differences (LSD) of chlorophyll measurements were calculated between treatments with a probability level of 0.05 for a specific growth stage.

Fifteen corn plants were hand harvested from each plot about 3 weeks after physiological maturity and dried in an airforced dryer at $60{ }^{\circ} \mathrm{C}$. Grain yields were adjusted to $15.5 \%$ moisture content and actual plant density. Relative yields for each treatment were obtained in accordance with the relative CMRs. The temporal pattern of relative CMRs was analyzed using regression analysis and tested for a significant trend using analysis of variance in Statistical Analysis System (SAS Inst., Cary, NC).

\section{RESULTS AND DISCUSSION}

\subsection{Divergence of chlorophyll measurements}

Figure 1 shows the temporal trend in CMRs (chlorophyll meter readings) during the growth of corn when all fertilizer $\mathrm{N}$ was applied soon after planting. The variation in growth stages among different treatments is not isolated from other measurement errors that are indicated by the vertical bars above the $\mathrm{X}$-axis. The magnitude of the bars indicates errors directly associated with use of the chlorophyll meters plus any additional errors associated with the assumption that plants on all plots were grown under identical conditions except for rates of $\mathrm{N}$ application. An important point illustrated in Figure 1 is that CMRs in all plots substantially changed as plants progressed through various stages of development. The lines that connect the same symbols between growth stages V6 and VT were almost linear and their slopes were related to rates of $\mathrm{N}$ applied. Therefore, $\mathrm{CMRs}$ measured during this period are strongly influenced by the rates of $\mathrm{N}$ fertilization. Another important point observed from Figure 1 is the similarity of trends of CMR development for the highest $\mathrm{N}$ rate over the time although the absolute CMRs are substantially different, with maximum values about 50 to 60 units. This variation could be attributed to the difference in variety or field conditions and was further confirmed by the difference of CMRs for the lowest $\mathrm{N}$ rate among the four sites.

Figure 2 shows temporal trends in relative CMRs with the same treatments as in Figure 1. Relative CMRs are conceived to minimize the effects of factors other than rates of $\mathrm{N}$ fertilization. However, the transformation of CMRs to relative CMRs could also transfer errors of measurement made in the reference plots to other plots because the mean of reference plots always has a value of $100 \%$. For example, a noteworthy greater error associated with CMRs taken from 14 to 30 days after June 1 was obviously due to the shift of chlorophyll measurements from various uppermost developed leaves to ear leaf. The difference in growth stages between the reference plot and other plots in this period has much greater influence on chlorophyll measurement than does the real difference in nitrogen status of corn plants. At least part of fluctuation in leaf chlorophyll measurements should be attributed to variation in upper most developed leaves, i.e., stages of plant growth or physiological age (Zhang et al., 2007).

An overall trend among the four sites in Figure 2 is that relative CMRs from plants having $\mathrm{N}$ rates less than $224 \mathrm{~kg} \mathrm{~N} \mathrm{ha}^{-1}$ diverge from the reference plants during several stages of growth. Relative yields of grain presented in Table II for each site also show that increases in rates of $\mathrm{N}$ application tended to delay the onset of deficiency symptoms, i.e., divergence of relative CMRs. This trend should be expected because $\mathrm{N}$ is consumed during the growth of corn and because supplies of $\mathrm{N}$ can be depleted during plant growth. Therefore, the $\mathrm{N}$ rate 

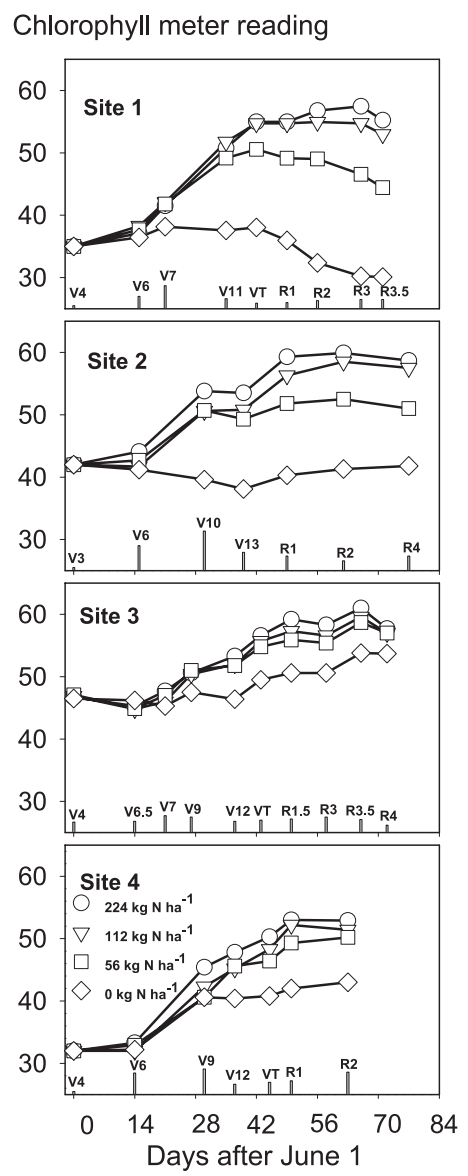

Figure 1. Temporal trends in chlorophyll meter readings for treatment with $\mathrm{N}$ fertilizer applied early in the season at four sites. Note the magnitude of vertical bars above the $\mathrm{X}$-axis that indicates the least significant difference at the probability level of $0.05\left(\mathrm{LSD}_{0.05}\right)$ of CMRs at various growth stages.

applied earlier should ensure sufficiency of $\mathrm{N}$ supply for the first development phases and then an adjusted in-season application should supplement.

Across the four sites, errors involved in relative CMRs are not constant due to differences in climate, soil, variety, etc. As shown in Figure 2, Sites 3 and 4 tended to have smaller errors in relative CMRs than did Sites 1 and 2. This finding is important for assessing the reliability and stability of the chlorophyll measurements when chlorophyll meters are used to help optimize in-season $\mathrm{N}$ fertilization under different site conditions. Addition of a fertilizer could supply young plants with adequate amounts of $\mathrm{N}$ for growth even in situations where the plants will soon experience shortages of $\mathrm{N}$ (Morris et al., 2006). This situation is impossible to describe unless the symptom of an $\mathrm{N}$ deficiency is clearly distinguished from the deficiency itself, i.e., amount of $\mathrm{N}$ fertilizer to correct deficiency.

In accordance with observations first made by Macy (1936), plant uptake of $\mathrm{N}$ is more likely to deplete concentrations of $\mathrm{N}$ than of $\mathrm{P}$ or $\mathrm{K}$ in soils because the concentrations of $\mathrm{N}$ in the soil solution are not highly buffered by chemical reactions
Relative chlorophyll meter reading (\%)

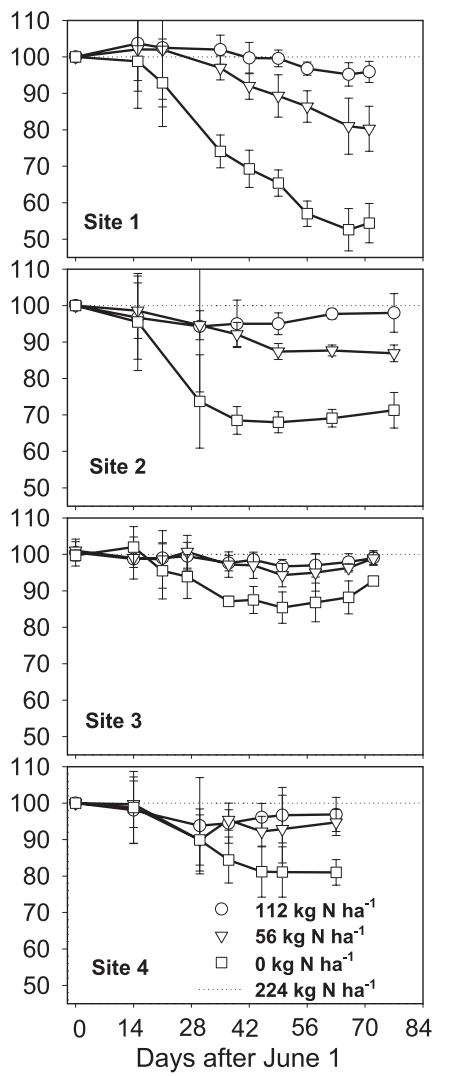

Figure 2. Temporal trends in relative chlorophyll meter readings for treatments with $\mathrm{N}$ fertilizer applied early in the season. Error bars represent \pm 1 standard deviation of the mean for each treatment on a specific measurement date. Note the divergence of three curves from the reference line $(100 \%)$.

Table II. Relative yields (\%) measured at physiological maturing stage from plants with early $\mathrm{N}$ fertilization.

\begin{tabular}{lcccc}
\hline N rate & Site 1 & Site 2 & Site 3 & Site 4 \\
$\left(\mathrm{kg} \mathrm{N} \mathrm{ha}^{-1}\right)$ & & & & \\
\hline 0 & 58 & 61 & 88 & 89 \\
56 & 85 & 84 & 95 & 95 \\
112 & 100 & 92 & 101 & 97 \\
224 & 100 & 100 & 100 & 100 \\
\hline
\end{tabular}

with the solid phase. The conclusion that supplies of $\mathrm{N}$ tend to be depleted as corn grows is consistent with observations of Binder et al. (2000), who observed that the yield reductions caused by delaying application of $\mathrm{N}$ were inversely related to supplies of $\mathrm{N}$ already in the soil.

\subsection{Convergence of chlorophyll measurements}

Figure 3 shows temporal trends in CMRs in plots where fertilizer-N treatments were applied after symptoms of $\mathrm{N}$ deficiency had already developed in some plots in addition to 
Chlorophyll meter reading

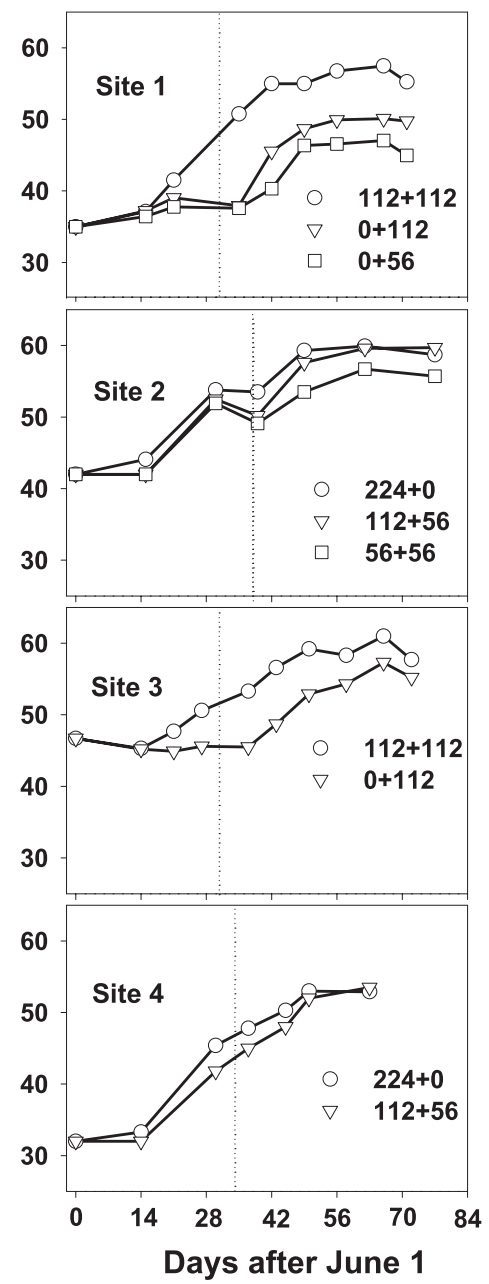

Figure 3. Temporal trends in chlorophyll meter readings for treatments with two applications of $\mathrm{N}$ fertilizer (in-season application date is indicated by a dotted line) at each of four sites.

some amount of fertilizer $\mathrm{N}$ applied soon after planting. Temporal trends in relative CMRs are shown in Figure 4. A key point illustrated is that in-season applications of $\mathrm{N}$ often cause relative CMRs to converge during the reproductive stages of growth. Addition of fertilizer, therefore, enabled relatively low CMRs to catch up with the CMRs of the reference plants. Situations where a series of at least three successive measurements showed a statistically significant positive slope as revealed by analysis of variance are indicated in Figure 4 with solid symbols. The observation that in-season application of fertilizer $\mathrm{N}$ enabled plants showing symptoms of $\mathrm{N}$ deficiency to catch up with plants always having adequate supplies of $\mathrm{N}$ suggests a phenomenon similar to luxury production of chlorophyll in plants that always had ample $\mathrm{N}$. This trend was observed for all four sites despite differences in factors such as location, climate, and growing season.

Plants with higher relative CMRs showed an evidence for luxury production of chlorophyll in the sense that their CMRs
Relative chlorophyll meter reading (\%)

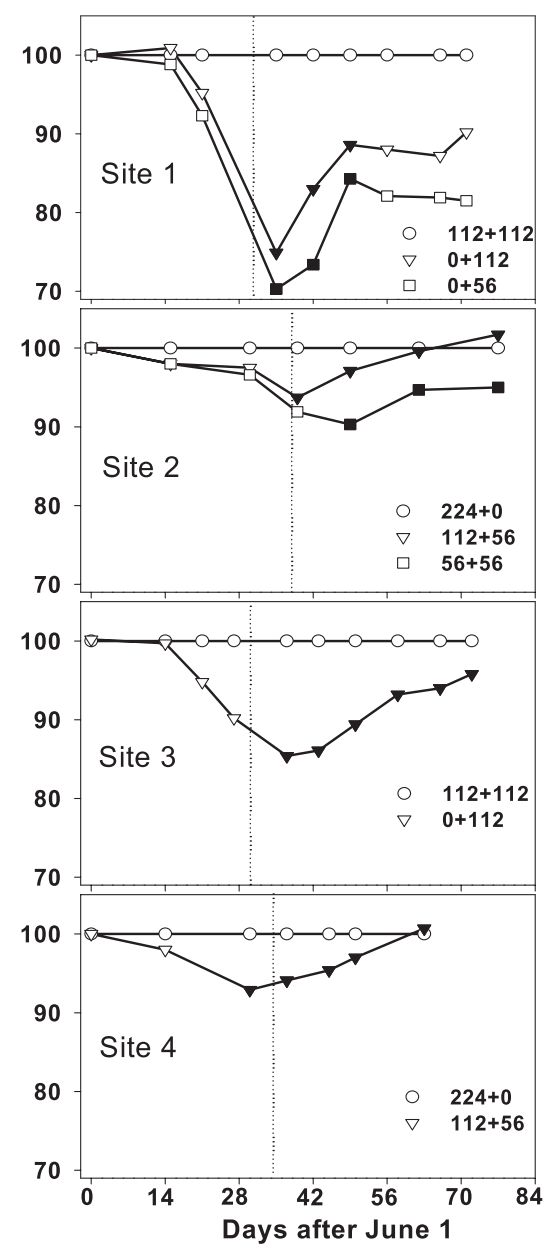

Figure 4. Temporal trends in relative chlorophyll meter readings for treatments with two applications of $\mathrm{N}$ fertilizer (in-season application date is indicated by a dotted line) at each of four sites. Note that the successive solid symbols on curves show statistically significant increase of relative CMRs that converge to the reference line (100\%).

were often higher than needed to produce optimal yields of grain (Fig. 4). In any case, the grain yield should be considered a reliable indicator of the potential recovery of corn from $\mathrm{N}$ deficiency (Tab. III). Such a situation could be expected if plant growth is recognized as a continuous process that occurs over a period of many weeks and factors other than $\mathrm{N}$ become limited during the growth. If rapid growth of vegetation early in the season depleted water needed for growth later in the season, for example, the rapid vegetative growth induced by a high level of $\mathrm{N}$ early in the season could be offset by shortages of water later in the season. This situation is important because the profitability of corn production is determined by yields of grain rather than yields of vegetation. It should be noted that factors other than water could be involved because data presented by Blackmer and Schepers (1995) shows that fertilizer added with irrigation can induce convergence of relative CMRs. 
Table III. Relative yields (\%) measured at physiological maturing stage from plants with early and in-season $\mathrm{N}$ fertilization.

\begin{tabular}{lccccc}
\hline N rate* & Site 1 & Site 3 & $\begin{array}{c}\text { N rate* } \\
\left(\mathrm{kg} \mathrm{Nha}^{-1}\right)\end{array}$ & Site 2 & Site 4 \\
$\left(\mathrm{kg} \mathrm{N} \mathrm{ha}^{-1}\right)$ & & & $56+0$ & 61 & 89 \\
\hline $0+56$ & 84 & 94 & $112+0$ & 84 & 95 \\
$0+112$ & 93 & 96 & $56+56$ & 98 & 94 \\
$56+56$ & 96 & 101 & $112+56$ & 99 & 97 \\
$56+112$ & 98 & 101 & $224+0$ & 100 & 100 \\
$112+112$ & 98 & 100 & \\
\hline
\end{tabular}

* Two rates of $\mathrm{N}$ fertilizer were applied soon after planting and as sidedress, respectively.

The observation that in-season application of fertilizer $\mathrm{N}$ enabled plants showing symptoms of $\mathrm{N}$ deficiency to catch up with plants always having adequate supplies of $\mathrm{N}$ also could be explained by $\mathrm{N}$-sufficiency levels that had changed the rate of crop maturation as well as the rate of growth (Blackmer, 2000). If a short period with inadequate $\mathrm{N}$ delayed crop development as well as reduced plant growth, for example, the effects of the deficiency could be offset by a longer period for crop growth (Zhang et al., 2007).

The effects of $\mathrm{N}$-sufficiency level on the rate of crop maturity are reported to be small (Blackmer and Schepers, 1995). As indicated in Figure 1 and Figure 3, however, CMRs changed rapidly with corn growth. The phenomenon of plants with symptoms of $\mathrm{N}$ deficiencies catching up with plants that always have adequate $\mathrm{N}$ should be expected in some situations where fertilizer $\mathrm{N}$ is not applied during the season (see Fig. 2, Site 3 and Site 4). High concentrations of nitrate often accumulate more than a meter below the soil surface (Liu et al., 2005), so effects similar to in-season fertilization should be expected as roots grow to these depths. Especially in soils having relatively high concentrations of soil organic matter, net mineralization of $\mathrm{N}$ from soil organic matter could supply more $\mathrm{N}$ than needed for plant growth during the second half of the growing season under some weather conditions.

\section{CONCLUSION}

In making decisions of when and how much $\mathrm{N}$ fertilizer should be applied, corn growers often rely on early deficiency symptoms of $\mathrm{N}$ they have visually observed on a non-fertilized window or a reference without $\mathrm{N}$ stress. An in-season plant analysis allows optimizing $\mathrm{N}$ fertilizer management with respect to economic and environmental considerations. This study with leaf chlorophyll measurements provides evidence that $\mathrm{N}$ deficiency and recovery can occur during the growth of corn. Chlorophyll content in corn leaves can completely or partially recover from a period when supplies of $\mathrm{N}$ are not adequate to maximize the chlorophyll production but the potential yield has not been reduced. Hence, leaf chlorophyll content does not have to be maintained at the highest possible levels at all stages of growth to maximize final yields of grain.

Our observations suggest that difficulties should be expected when trying to precisely define critical levels of CMRs that should be obtained early in the season to maximize yields of grain. Above-optimal amounts of leaf chlorophyll clearly can occur at some stages of growth, and it makes little difference whether this is described as luxury production of chlorophyll or a result of interaction between shortages of water and nutrients other than $\mathrm{N}$ needed to support growth. These effects of above-optimal supplies of $\mathrm{N}$ cannot be described by twocategory diagnostic systems that consider plants to be either deficient or non-deficient with respect of $\mathrm{N}$. This problem is exacerbated by the possibility that above-optimal supplies of $\mathrm{N}$ at some stages of growth may reduce yields of grain without having a toxic effect on plants.

The aforesaid problems can be avoided by: (1) clarifying whether the specific objective of applying $\mathrm{N}$ is to produce vegetation or grain, (2) acknowledging that the optimal content of chlorophyll is less than the maximum for economic and environmental reasons, (3) describing supplies of $\mathrm{N}$ in terms of $\mathrm{N}$-sufficiency levels by using scales that range from belowoptimal to above-optimal, and (4) recognizing that the deficiency of $\mathrm{N}$ for plant growth at near-optimal supplies of $\mathrm{N}$ should be expected to vary during growth due to unpredictable factors that can have different effects on supplies of $\mathrm{N}$ in soils and demand for $\mathrm{N}$ by plants.

Acknowledgements: The research project was partially funded by Case New Holland (formally Case $\mathrm{IH}$ ) through the coordination of Dr. Larry Hendrickson. Field data collection was assisted by Matt Dickson, Joseph Sines and Heather Kenyon-Clark. Maureen Schaber of the Pacific Agri-Food Research Centre, Agassiz, BC Canada and other anonymous reviewers carefully read the original manuscript with constructive suggestions.

\section{REFERENCES}

Binder D.L., Sander D.H., Walters D.T. (2000) Maize response to time of nitrogen application as affected by level of nitrogen deficiency, Agron. J. 92, 1228-1236.

Binford G.D., Blackmer A.M., El-Hout N.M. (1990) Tissue test for excess nitrogen during corn production, Agron. J. 82, 124-129.

Binford G.D., Blackmer A.M., Meese B.G. (1992) Optimal concentrations of nitrate in cornstalks at maturity, Agron. J. 84, 881-887.

Blackmer A.M. (2000) Bioavailability of nitrogen, in: Sumner M.E. (Ed.), Handbook of soil science, CRC Press, Boca Raton, FL, pp. D3-D18.

Blackmer T.M., Schepers J.S. (1995) Use of a chlorophyll meter to monitor $\mathrm{N}$ status and schedule fertigation, J. Prod. Agric. 8, 56-60

Denuit J.P., Olivier M., Goffaux M.J., Herman J.L., Goffart J.P., Destain J.P., Frankinet M. (2002) Management of nitrogen fertilization of winter wheat and potato crops using the chlorophyll meter for crop nitrogen status assessment, Agronomie 22, 847-853.

Fox R.H., Piekielek W.P., Macneal K.E. (2001) Comparison of lateseason diagnostic tests for predicting nitrogen status of corn, Agron. J. 93, 590-597.

Greenwood E.A.N. (1976) Nitrogen stress in plants, Adv. Agron. 28, 135.

Hussain F., Bronson K.F., Singh Y., Singh B., Peng S. (2000) Use of chlorophyll meter sufficiency indices for nitrogen management of irrigated rice in Asia, Agron. J. 92, 875-879. 
Jemison J.M. Jr., Lytle D.E. (1996) Field evaluation of two nitrogen test methods in Maine, J. Prod. Agric. 9, 108-113.

Kyveryga P.M. (2005) Calculating ex post economic optimum rates of nitrogen fertilization for corn, Dissertation, Iowa State University, Ames, Iowa.

Liu G.D., Wu W.L., Zhang J. (2005) Regional differentiation of non-point source pollution of agriculture-derived nitrate nitrogen in groundwater in northern China, Agr. Ecosyst. Environ. 107, 211-220.

Macy P. (1936) The quantitative mineral nutrient requirements of plants, Plant Physiol. 11, 749-764.

Morris K.B., Martin K.L., Freeman K.W., Teal R.K., Girma K., Arnall D.B., Hodgen P.J., Mosali J., Raun W.R., Solie J.B. (2006) Mid-season recovery from nitrogen stress in winter wheat, J. Plant Nutr. 29, 727-745.

Peterson T.A., Blackmer T.M., Francis D.D., Schepers J.S. (1993) Using a chlorophyll meter to improve N management. Neb Guide G 931171-A, Coop. Ext. Univ. of Nebraska, Lincoln.

Piekielek W.P., Fox R.H. (1992) Use of a chlorophyll meter to predict sidedress nitrogen requirements for maize, Agron. J. 84, 59-65.

Piekielek W.P., Fox R.H., Toth J.D., Macneal K.E. (1995) Use of a chlorophyll meter at the early dent stage of corn to evaluate nitrogen sufficiency, Agron. J. 87, 403-408.

Ritchie S.W., Hanway J.J., Benson G.O. (1993) How a corn plant grows, Iowa State Ext. Serv. Spec. Rep. 48, Iowa State Univ., Ames, IA.
Shapiro C.A. (1999) Using a chlorophyll meter to manage nitrogen applications to corn with high nitrate irrigation water, Commun. Soil Sci. Plant Anal. 30, 1037-1049.

Scharf P.C., Brouder S.M., Hoeft R.G. (2006) Chlorophyll meter readings cann predict nitrogen need and yield response of corn in the NorthCentral USA, Agron. J. 98, 655-665.

Schepers J.S., Blackmer T.M., Francis D.D. (1992) Using chlorophyll meters, in: Bock B.R., Kelley K.R. (Eds.), Predicting N fertilizer needs for corn in humid regions, Bull. Y-226, Natl. Fert. Environ. Res. Ctr. TVA, Muscle Shoals, AL, pp. 105-114.

Schepers J.S., Francis D.D., Vigil M., Below F.E. (1992) Comparison of corn leaf nitrogen concentration and chlorophyll meter readings, Commun. Soil Sci. Plant Anal. 23, 2173-2187.

Varvel G.E., Schepers J.S., Francis D.D. (1997) Ability for in-season correction of nitrogen deficiency in corn using chlorophyll meters, Soil Sci. Soc. Am. J. 61, 1233-1239.

Wood C.W., Reeves D.W., Himelrick D.G. (1993) Relationship between chlorophyll meter readings and leaf chlorophyll concentration, $\mathrm{N}$ status, and crop yields: A review, Proc. Agron. Soc. New Zealand $23,1-9$.

Zhang J., Blackmer A.M. (1999) Monitoring nitrogen deficiencies in corn, Integrated Crop Management, Special Precision Ag Edition 5-6.

Zhang J., Blackmer A.M., Blackmer T.M. (2007) Check for differences in physiological age when diagnosing deficiencies of nitrogen in cornfields, J. Agron. (in press). http://www.ansijournals.com/ja/o/166JA-2k6.pdf. 